\title{
Obojestranska prednost $v$ vidnem delovnem spominu je opazna šele ob preseženi spominski kapaciteti posamezne hemisfere
}

\author{
Anka Slana Ozimič* in Grega Repovš \\ Oddelek za psihologijo, Filozofska fakulteta, Univerza v Ljubljani
}

\begin{abstract}
Povzetek: Temeljno raziskovalno vprašanje na področju preučevanja vidnega delovnega spomina je, kateri mehanizmi vzdrževanja vidnih informacij so podlaga za njegovo omejeno kapaciteto. Študije kažejo na pomembno vlogo posteriornih področij možganov, ki omogočajo oblikovanje vidnih reprezentacij na podlagi kontralateralne organiziranosti vidnega sistema. Ta omogoča, da si posamezniki zapomnijo več informacij, kadar so te prikazane na obeh polovicah vidnega polja in jih posledično procesirata obe hemisferi. Gre za pojav, ki je poznan kot obojestranska prednost. Na podlagi dosedanjih spoznanj o obojestranski prednosti pri hranjenju vidnih informacij je bil cilj naše raziskave preveriti, na kateri stopnji obremenjenosti vidnega delovnega spomina pride do obojestranske prednosti in ali lahko udeleženci pri obojestranskem prikazu informacij popolnoma izkoristijo skupno spominsko kapaciteto leve in desne hemisfere. V eksperimentu je sodelovalo 18 študentov (13 žensk), starih med 19 in 41 let, ki so izvedli nalogo prepoznave sprememb, pri kateri so morali prepoznati spremembo v orientaciji objektov, prikazanih na levi, desni ali na obeh straneh vidnega polja. Rezultati so pokazali, da so si udeleženci zapomnili več vidnih informacij in podajali hitrejše odgovore, kadar so bili objekti razporejeni preko obeh polovic vidnega polja, kar je skladno s predpostavko, da pri obojestranskem prikazu objektov izkoriščamo kapaciteto obeh hemisfer. V nadaljevanju so rezultati pokazali, da je obojestranska prednost opazna šele takrat, ko obremenitev vidnega delovnega spomina preseže kapaciteto posamezne hemisfere. Kljub pomembni obojestranski prednosti le-ta udeležencem ne omogoča, da dosežejo skupno kapaciteto obeh hemisfer, kar nakazuje, da kapaciteta vidnega delovnega spomina ni omejena le s sposobnostjo oblikovanja reprezentacij, temveč da jo opredeljujejo omejitve dodatnega kognitivnega sistema.
\end{abstract}

Ključne besede: vidni delovni spomin, vidne reprezentacije, vzdrževanje, kapaciteta, obojestranska prednost

\section{Bilateral advantage in visual working memory is observed when individual hemisphere's capacity is exceeded}

\author{
Anka Slana Ozimič $\check{c}^{*}$ and Grega Repovš \\ Department of Psychology, Faculty of Arts, University of Ljubljana, Slovenia
}

\begin{abstract}
What are the mechanisms of visual information maintenance that underlie its highly limited capacity is a key question in visual working memory research. Previous studies emphasized the role of posterior brain regions, which enable the formation of visual representations. Their contralateral organization allows individuals to maintain more information when they are presented across both visual hemifields and are processed by both hemispheres. This phenomenon is known as bilateral advantage. Based on previous findings on bilateral advantage in visual information maintenance, the aim of our study was to assess at what working memory load can bilateral advantage be observed, and whether in the case of bilateral presentation of information participants can take full advantage of joint left and right hemisphere's capacities. Eighteen students (13 woman) aged between 19 and 41 participated in the study and completed a change detection task, in which they were asked to recognize a change in the orientation of the objects presented to the left, right, or both visual hemifields. The results showed that the participants were able to maintain more visual information and gave quicker responses when objects were distributed across both visual hemifields, which is in line with the assumption that bilateral display facilitates the use of both hemispheres' capacities. Furthermore, the results showed that bilateral advantage occurs only when visual working memory load exceeds the capacity of the individual hemispheres. Despite significant bilateral advantage, bilateral presentation of visual information, however, does not allow the participants to utilize the full joint capacity of the two hemispheres, suggesting that the capacity of visual working memory is limited not only by the ability to form representations, but also by an additional cognitive system.
\end{abstract}

Keywords: visual working memory, visual representations, maintenance, capacity, bilateral advantage

\footnotetext{
*Naslov/Address: Anka Slana Ozimič, Oddelek za psihologijo, Filozofska fakulteta, Univerza v Ljubljani, Aškerčeva 2, 1000 Ljubljana, e-mail: anka.slana@ff.uni-lj.si
}

Članek je licenciran pod pogoji Creative Commons Attribution 4.0 International licence. (CC-BY licenca).

The article is licensed under a Creative Commons Attribution 4.0 International License (CC-BY license). 
Delovni spomin, sposobnost vzdrževanja in aktivnega manipuliranja $\mathrm{z}$ informacijami za dosego trenutnega cilja, je ena ključnih kognitivnih sposobnosti (Baddeley, 1996a). Delovni spomin je pomemben za opravljanje vsakodnevnih aktivnosti, kot so reševanje problemov, načrtovanje, branje in učenje, hkrati pa predstavlja temelj k cilju usmerjenega vedenja (Baddeley, 1996b). Visoko korelira s splošno inteligentnostjo (Cowan, 2005) in je pogosto oškodovan pri boleznih možganov, tj. pri boleznih od shizofrenije (GoldmanRakic, 1994), Alzheimerjeve demence (Kensinger, Shearer, Locascio, Growdon in Corkin, 2003) do Parkinsonove bolezni (Bublak, Müller, Grön, Reuter in von Cramon, 2002), njegov upad pa je značilen tudi za zdravo staranje (Braver in West, 2007; Park in Festini, 2017). Zaradi njegove osrednje vloge v kogniciji je raziskovanje temeljnih mehanizmov delovnega spomina izrednega pomena za razumevanje človeške kognicije v zdravju in bolezni.

Osrednji teoretski okvir preučevanja delovnega spomina v okviru kognitivne psihologije predstavlja Baddeleyjev in Hitchev (1974; Baddeley, 2000; Repovš in Baddeley, 2006) multikomponentni model delovnega spomina. Kot pove že ime samo, model predvideva delitev delovnega spomina na več komponent, in sicer na fonološko zanko, ki je zadolžena za vzdrževanje verbalnih informacij, vidno-prostorsko skicirko, ki hrani vidne in prostorske informacije, in epizodični medpomnilnik, katerega naloga je hranjenje integriranih informacij različnih modalnosti v obliki kratkih epizod in povezovanje $\mathrm{z}$ dolgoročnim spominom. Zadnja komponenta je centralni izvršitelj, ki nadzoruje in upravlja celotni sistem ter omogoča manipulacijo $\mathrm{z}$ informacijami, hranjenimi $\mathrm{v}$ njem.

Raziskovalno delo je bilo sprva posvečeno predvsem preverjanju predpostavk modela, vezanih na jezikovni delovni spomin, kasneje pa se je pozornost preusmerila na preučevanje vidnega delovnega spomina. Eno izmed ključnih raziskovalnih vprašanj se nanaša na mehanizme, ki so podlaga za njegovo omejeno kapaciteto. Raziskave kažejo, da je v vidnem delovnem spominu hkrati možno vzdrževati le 3 do 4 objekte (Cowan, 2010). V sklopu preučevanja kapacitete vidnega delovnega spomina so aktualne številne znanstvene diskusije, npr. ali je kapaciteta vidnega delovnega spomina omejena s številom diskretnih reprezentacij ali z neomejeno deljenimi viri (npr. Luck in Vogel, 2013; Ma, Husain in Bays, 2014) in ali omejitve izhajajo iz modalno-specifičnih shramb $\mathrm{v}$ delovnem spominu ali iz omejitev $\mathrm{v}$ procesih pozornosti (Cowan, 2010). V naši raziskavi nas je zanimalo, kako kapaciteto vidnega delovnega spomina opredeljuje organiziranost možganskega sistema za procesiranje vidnih informacij.

Nevrofiziološke raziskave vidnega delovnega spomina kažejo na specifično delitev vloge posteriornih in prefrontalnih področij možganske skorje pri vzdrževanju informacij $\mathrm{v}$ vidno-prostorskem delovnem spominu (Eriksson, Vogel, Lansner, Bergström in Nyberg, 2015; Riggall in Postle, 2012). Študije nakazujejo, da so posteriorna področja tista, ki beležijo vidne oziroma prostorske reprezentacije, medtem ko so prefrontalna področja odgovorna za njihovo aktivno vzdrževanje v odsotnosti zunanjih dražljajev. Možganska področja, ki beležijo reprezentacije $\mathrm{v}$ posteriornih področjih možganske skorje, se v veliki meri prekrivajo s sistemom za zgodnje procesiranje vidno-prostorskih informacij (Alvarez in Cavanagh, 2005; Vogel in Machizawa, 2004), ki je organiziran kontralateralno. Informacije, predstavljene na levi strani vidnega polja, so sprva procesirane $\mathrm{v}$ vidnih področjih desne možganske hemisfere, in obratno (Bullier, 2004). Kadar sta v procesiranje vidnih informacij vključeni obe hemisferi, tj. ko so informacije, ki jih mora posameznik procesirati, predstavljene preko obeh strani vidnega polja, se to odraža $v$ večji zmogljivosti vidnega procesiranja. Ta pojav je poznan kot obojestranska prednost (angl. bilateral advantage) (Delvenne, 2012).

Obojestranska prednost je bila prikazana skozi številne naloge vidnega procesiranja, kot so npr. identifikacija orientacij (Chakravarthi in Cavanagh, 2009), identifikacija črk (Kraft idr., 2013) in sledenje objektom (Alvarez in Cavanagh, 2005). Rezultati študij kažejo, da je izvedba nalog boljša, kadar so informacije prikazane na obeh straneh vidnega polja, kar nakazuje, da imata leva in desna hemisfera ločene vire za procesiranje vidnih informacij (Chakravarthi in Cavanagh, 2009). Navedena spoznanja so skladna $\mathrm{s}$ hipotezo o vzporednem procesiranju vidnih informacij, ki je učinkovitejše, kadar procesiranje informacij poteka preko obeh hemisfer, kot takrat, ko poteka znotraj ene same (Kraft idr., 2013).

Medtem ko poteka zgodnje procesiranje vidnih informacij na kontralateralni način $\mathrm{v}$ posteriornih možganskih regijah, za višje procesiranje vidnih informacij (predvidoma v prefrontalnih področjih možganov) hemisferna lateralizacija ni značilna, kar pomeni, da sta vanj vključeni obe hemisferi (Alvarez in Cavanagh, 2005), ki informacije ne glede na stran vidnega polja, na kateri so prikazane, izmenjujeta preko korpusa kalozuma (Delvenne, 2012). Ta spoznanja so omogočila preverjanje predpostavk o tem, na kateri stopnji vidnega procesiranja in $\mathrm{v}$ katerih področjih možganske skorje se oblikujejo in so shranjene reprezentacije v vidnem delovnem spominu. Več študij, tako vedenjskih (npr. Delvenne, 2012; Umemoto, Drew, Ester in Awh, 2010) kot nevrofizioloških (npr. Vogel in Machizawa, 2004), kaže, da so reprezentacije vsaj do neke mere hranjene v hemisferi, ki je kontralateralna strani vidnega polja, v katerem je objekt prikazan, kar kaže na pomembno vlogo posteriornih, kontralateralno organiziranih področij vidnega procesiranja pri vzdrževanju informacij $\mathrm{v}$ vidnem delovnem spominu.

Če razložimo podrobneje, vedenjske raziskave obojestranske prednosti so pokazale, da so si udeleženci sposobni zapomniti več informacij, kadar so objekti razpršeni preko obeh polovic vidnega polja, kot kadar so prikazani samo znotraj leve ali desne polovice vidnega polja. Razporeditev objektov preko obeh polovic vidnega polja namreč omogoča razporeditev njihovih reprezentacij preko obeh hemisfer, medtem ko je v procesiranje in vzdrževanje informacij, kadar so prikazane samo na eni polovici vidnega polja, vključena le ena hemisfera. Ko si je npr. treba zapomniti orientacijo štirih dražljajev, prikazanih na levi polovici vidnega polja, so posteriorna področja desne hemisfere bolj obremenjena z vzpostavljanjem individualnih reprezentacij, kot kadar so štirje dražljaji razporejeni preko levega in desnega vidnega polja (na vsaki polovici po dva dražljaja) in sta obremenjeni obe 
hemisferi, vendar vsaka v manjši meri. Takšna obojestranska prednost je bila prikazana v raziskavah, ki so od udeležencev zahtevale vzdrževanje orientacij (Umemoto idr., 2010), lokacij (Delvenne, 2005) in barv (Holt, 2014).

Neposrednejši dokaz za pomen parietalno-okcipitalnih področij in njihove hemisferične specializacije pri vzdrževanju informacij $\mathrm{v}$ vidnem delovnem spominu podajajo EEG študije (za pregled glej Luria, Balaban, Awh in Vogel, 2016; Vogel in Machizawa, 2004), ki kažejo na zvišanje električne aktivnosti nad parietalno-okcipitalnimi področji možganske skorje v hemisferi, kontralateralni vidnemu polju, v katerem je bil objekt prikazan.

Skupno predstavljene študije (npr. Holt, 2014; Vogel in Machizawa, 2004) kažejo na kontralateralno organiziranost vidnega sistema tako pri zgodnjem procesiranju vidnih informacij kot tudi pri njihovem vzdrževanju $\mathrm{v}$ delovnem spominu. Zaključimo lahko, da imata leva in desna hemisfera ločene vire ne le za procesiranje vidnih informacij, temveč tudi za oblikovanje njihovih reprezentacij, ki jih vzdržujemo $\mathrm{v}$ vidnem delovnem spominu. Iz teh spoznanj sledi, da je kapaciteta delovnega spomina primarno določena $\mathrm{s}$ sposobnostjo oblikovanja reprezentacij $\mathrm{V}$ posamezni hemisferi, zaradi česar je pri merjenju kapacitete vidnega delovnega spomina treba upoštevati zmogljivost tako obeh hemisfer kot vsake posamične.
Čeprav študije (za pregled glej Delvenne, 2012) kažejo na obojestransko prednost pri pomnjenju različnih vidnih lastnosti (npr. orientacij, barv, lokacij), pa ne naslavljajo vprašanja, na kateri stopnji obremenjenosti vidnega delovnega spomina je obojestransko prednost sploh mogoče zaznati, na kar želimo odgovoriti s to študijo. Predpostavljamo, da ob nižji obremenjenosti vidnega delovnega spomina, tj. ko morajo udeleženci vzdrževati manj informacij, kot je največja zmogljivost posamezne hemisfere, do obojestranske prednosti ne bo prišlo, saj bo vsaka posamezna hemisfera zmožna sama vzdrževati vse predstavljene informacije, in to ne glede na to, ali bodo te predstavljene enostransko (na levi ali desni polovici vidnega polja) ali obojestransko (razporejene preko obeh strani vidnega polja) (slika 1A). Obojestranska prednost se bo pokazala šele takrat, ko bo pri posamezniku število objektov, ki si jih mora zapomniti, preseglo spominsko kapaciteto posamezne hemisfere, saj bosta $\mathrm{v}$ primeru obojestranskega prikaza objektov hemisferi manj obremenjeni in bo lahko vsaka shranila del predstavljenih informacij (slika 1B).

Dodatno bomo preverili, ali lahko udeleženci v primeru obojestranskega prikaza informacij polno izkoristijo skupno kapaciteto leve in desne hemisfere - ali torej izmerjena kapaciteta pri obojestranskem prikazu doseže vsoto kapacitet, izmerjenih za enostranski prikaz dražljajev na levi in desni
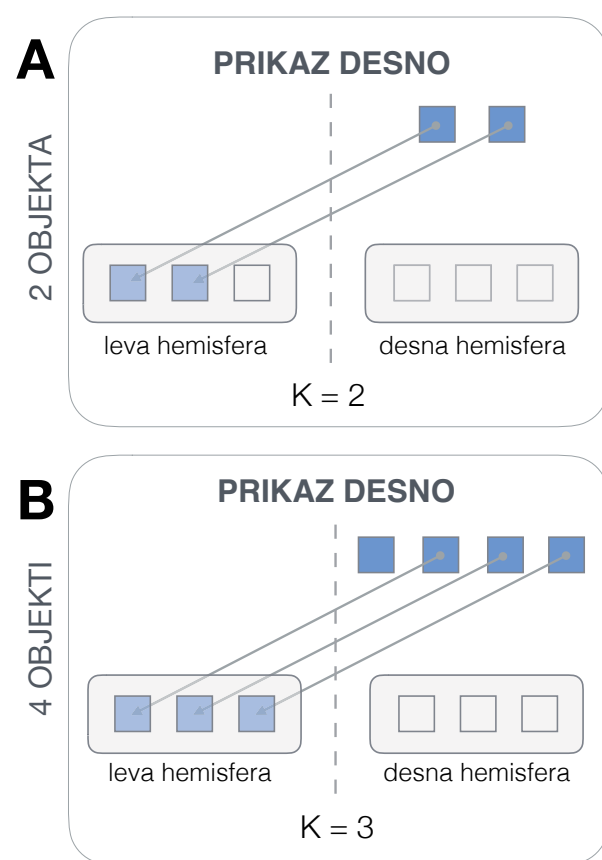
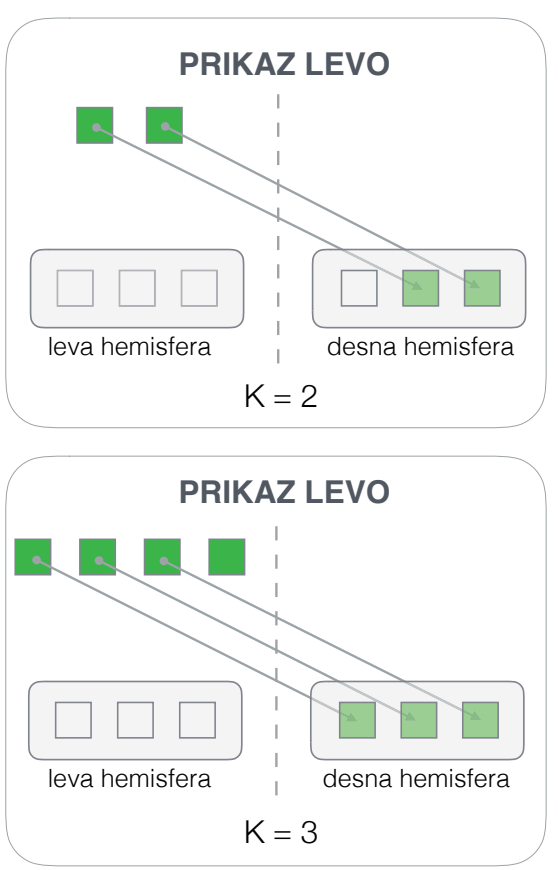
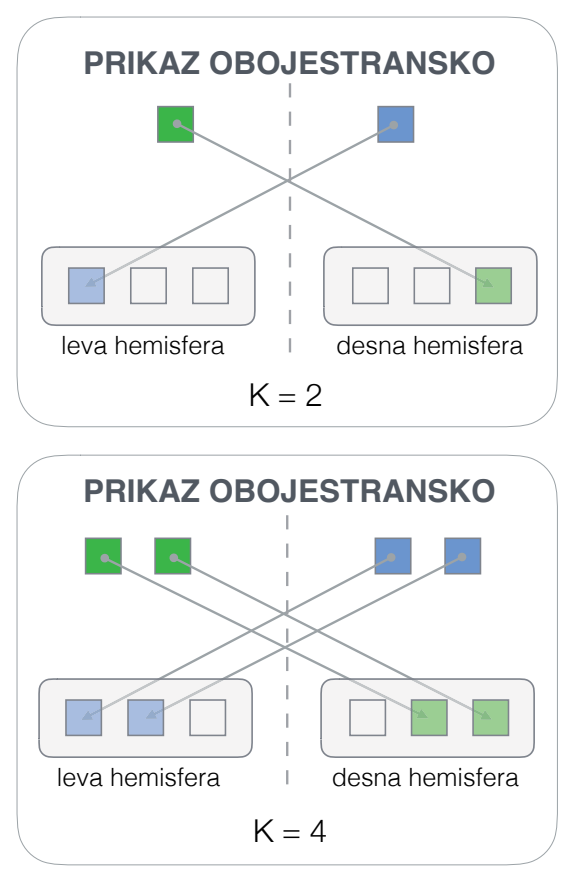

Slika 1. Hipotetični potek izvedbe naloge vidnega delovnega spomina in rezultati. Kvadratki v zgornji vrstici vsakega posameznega pogoja predstavljajo objekte, katerih vidno lastnost si mora udeleženec zapomniti, kvadratki v spodnjih vrsticah pa razpoložljive spominske reže. Pobarvani kvadratki v spodnjih vrsticah označujejo spominske reže, zasedene z reprezentacijami predstavljenih objektov (povezano s sivo puščico), prazni kvadratki označujejo neizkoriščene spominske reže. (A) Naloga udeleženca je zapomniti si dva objekta, prikazana na desni ali levi strani ali preko obeh polovic vidnega polja. Ker je udeleženčeva kapaciteta vsake hemisfere tri objekte, si je udeleženec v vseh treh primerih sposoben zapomniti oba prikazana objekta. Njegova izmerjena kapaciteta $(\mathrm{K})$ je 2, saj število prikazanih objektov ne presega kapacitete vsake posamezne hemisfere. (B) Udeleženec si mora zapomniti štiri objekte, prikazane na desni ali levi strani ali preko obeh polovic vidnega polja, pri čemer je kapaciteta vsake izmed hemisfer tri objekte. V primeru enostranskega prikaza (desno, levo) bo udeleženčeva izmerjena kapaciteta tri objekte (enega izmed prikazanih objektov ne bo mogel vzdrževati), medtem ko bo v primeru obojestranskega prikaza izmerjena kapaciteta 4, saj bosta v vzdrževanje prikazanih objektov v spominu vključeni obe hemisferi. 


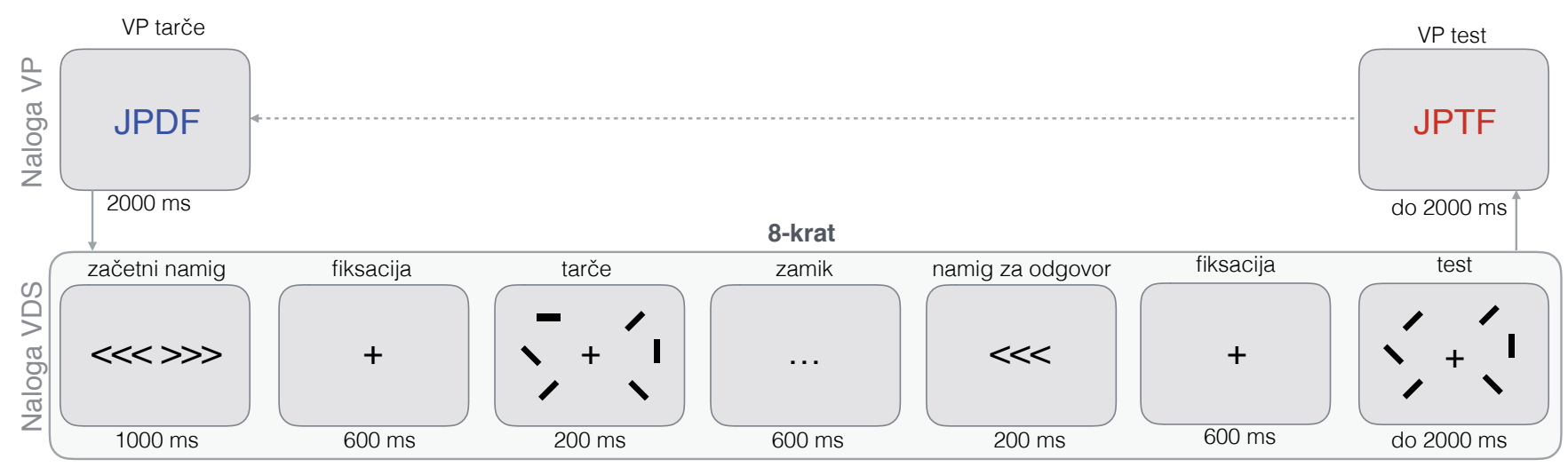

Slika 2. Potek naloge vidnega delovnega spomina in struktura poskusov. V zgornjem delu slike je prikazan potek naloge verbalne potlačitve (naloga VP). Spodnji del slike prikazuje potek naloge vidnega delovnega spomina (naloga VDS). Razmerja med prikazanimi dražljaji na sliki niso realna (za natančne mere glej besedilo članka).

strani zaslona, definirano kot obojestranski potencial. Če bi obojestranska kapaciteta dosegla obojestranski potencial, bi lahko sklepali, da omejitev kapacitete delovnega spomina primarno temelji na zmogljivosti posteriornih področij možganov leve in desne hemisfere, ki so odgovorna za vzpostavljanje reprezentacij vidnih objektov. V primeru, da bo obojestranska kapaciteta manjša od njune vsote, bi to kazalo, da kapaciteto vidnega delovnega spomina nadalje omejujejo dodatna možganska (potencialno tista) področja, ki omogočajo aktivno vzdrževanje vzpostavljenih reprezentacij v odsotnosti zunanjih dražljajev.

Glede na hipotezo o vzporednem procesiranju vidnih informacij, ki je učinkovitejše $\mathrm{v}$ primeru obojestranskega prikaza dražljajev $\mathrm{v}$ nasprotju $\mathrm{z}$ enostranskim, nas zanima tudi, ali se bo to odražalo v času, ki ga udeleženec potrebuje za procesiranje vidnih objektov in podajo odgovora o njihovi identiteti. Predpostavljamo, da lahko v primeru obojestranske predstavitve udeleženci $\mathrm{v}$ večji meri vzporedno procesirajo dražljaje in bodo zato reakcijski časi krajši, kot kadar bo enako število objektov prikazano le znotraj leve ali desne polovice vidnega polja. Dodatno nas zanima, ali se bo tovrsten vzorec rezultatov, podobno kot pričakujemo pri kapaciteti, kazal le pri višji obremenjenosti vidnega delovnega spomina, torej ko obremenitev presega spominsko kapaciteto posamezne hemisfere.

\section{Metoda}

\section{Udeleženci}

Osemnajst študentov psihologije in kognitivne znanosti (trinajst žensk), starih med 19 in 41 let $(M=22,1, S D=$ $6,3)$, se je udeležilo enournega eksperimentalnega srečanja, na katerem so izvajali nalogo vidnega delovnega spomina. Vsi udeleženci so imeli normalen vid, nihče ni poročal o nevroloških motnjah. Vsi udeleženci, razen enega, so bili desnoročni. Podatke treh udeležencev smo predhodno izločili iz analize zaradi (1) prekoračitve časovne omejitve pri podaji odgovorov pri več kot polovici poskusov, (2) nizke pravilnosti pri nalogi vidnega delovnega spomina ( $v$ vsaj enem izmed eksperimentalnih pogojev je bila pravilnost manjša od naključja) in (3) pravilnosti, manjše od 75 odstotkov, pri sočasni nalogi verbalne potlačitve (priloga, slika P1), katere cilj je bil preprečiti verbalno prekodiranje vidno predstavljenih dražljajev, kot je podrobneje predstavljeno $\mathrm{v}$ nadaljevanju. Pred pričetkom eksperimentalnega srečanja so bili udeleženci seznanjeni $\mathrm{z}$ raziskavo in so podpisali obveščeno soglasje. Raziskavo je potrdila Komisija za etiko Filozofske fakultete Univerze v Ljubljani. S sodelovanjem v raziskavi so udeleženci lahko opravili del obveznosti pri študiju.

\section{Pripomočki}

Dražljaji. Tarčni dražljaji so bili v obliki pravokotnikov $\left(60 \times 20\right.$ zaslonskih pik; $1,39^{\circ} \times 0,46^{\circ}$ vidnega kota $)$. Orientacija vsakega izmed njih je bila naključno izbrana med štirimi možnimi orientacijami (horizontalno, vertikalno in obe diagonali). Dražljaji so bili prikazani znotraj navideznega kvadrata na vsaki strani zaslona. Stranica navideznega kvadrata je merila 250 zaslonskih pik $\left(5,75^{\circ}\right.$ vidnega kota), pri čemer se je središče kvadrata nahajalo 300 zaslonskih pik $\left(6,89^{\circ}\right.$ vidnega kota) levo in desno od centralne fiksacijske točke. Natančni položaj dražljajev znotraj kvadrata se je naključno spreminjal od poskusa do poskusa, pri čemer smo zagotovili, da je bila minimalna razdalja med središčema vseh parov prikazanih pravokotnikov vsaj dvakratnik njihove dolžine.

Da bi se izognili možnosti pojava in uporabe vidnih paslik, smo uporabili nizek kontrast med tarčnimi dražljaji in ozadjem - tarče so bile prikazane v črni barvi na sivem ozadju. Pilotno testiranje naloge je pokazalo, da do paslik, ki bi omogočale njihovo uporabo pri izvedbi naloge, ne prihaja.

Dražljaje smo prikazovali na 22 palčnem računalniškem zaslonu Samsung SyncMaster 2243BW z ločljivostjo 1680 $\times 1050$ zaslonskih pik in s hitrostjo osveževanja $60 \mathrm{~Hz}$. Eksperimentalno nalogo, ki je omogočala prikazovanje dražljajev in beleženje odgovorov, podanih s tipkovnico, smo oblikovali s pomočjo skripte v programu PsychoPy 2, verzija 1.78 (Peirce, 2007). 
Naloga vidnega delovnega spomina. Naloga je temeljila na lateralizirani različici naloge prepoznave sprememb (angl. change detection task; za pregled glej Luria idr., 2016). Naloga je vsebovala več poskusov s časovno strukturo, primerljivo s predhodnimi študijami (za pregled glej Delvenne, 2012; slika 2). Udeležencem je bil na zaslonu najprej za $1000 \mathrm{~ms}$ prikazan začetni namig, ki je označeval stran zaslona (levo, desno, oboje), s katere so si morali v nadaljevanju zapomniti orientacijo prikazanih dražljajev. Po zamiku $600 \mathrm{~ms}$, med katerim je bil na zaslonu prikazan le fiksacijski križec, so se za $200 \mathrm{~ms}$ na obeh straneh zaslona prikazali črni pravokotniki različnih orientacij. Udeleženci so si morali med vzdrževanjem pogleda na fiksacijsko točko v središču zaslona zapomniti orientacije pravokotnikov (tarč) na strani zaslona, ki je sovpadala $\mathrm{z}$ začetnim namigom (kadar je začetni namig označeval levo ali desno stran zaslona, so bili pravokotniki, prikazani na nasprotni strani zaslona, v vlogi motečih dražljajev; kadar je začetni namig označeval obe strani zaslona, so bili vsi prikazani pravokotniki tarče). Po zamiku $600 \mathrm{~ms}$, med katerim so udeleženci morali v spominu vzdrževati orientacije tarč, je bil za $200 \mathrm{~ms}$ prikazan namig za odgovor, ki je nakazoval stran zaslona (levo ali desno), na podlagi katerega so morali udeleženci oblikovati svoj odgovor. Po vnovičnem zamiku $600 \mathrm{~ms}$ je bil za $2000 \mathrm{~ms}$ prikazan testni niz dražljajev na obeh straneh zaslona. Med tem časom so morali udeleženci s pritiskom na ustrezno tipko na računalniški tipkovnici označiti, ali je prišlo do spremembe v orientaciji katerega koli tarčnega dražljaja na relevantni strani zaslona ali ni prišlo do spremembe, medtem ko so morali morebitno spremembo na nerelevantni strani zaslona ignorirati. Kadar je začetni namig označeval levo ali desno stran zaslona, se je le-ta vedno skladal z namigom za odgovor. Kadar je začetni namig označeval obe strani zaslona, je bilo treba odgovor podati le za relevantno (levo ali desno) stran zaslona, kot je bilo nakazano $\mathrm{z}$ namigom za odgovor. $\mathrm{S}$ tem smo zagotovili, da sta bila pogoja enostranskega in obojestranskega prikaza primerljiva $\mathrm{v}$ načinu usmerjanja pozornosti pri podajanju odgovorov. V nalogi smo beležili pravilnost odgovorov in njihov reakcijski čas.

Takšna eksperimentalna struktura nam je omogočila oblikovanje 13 eksperimentalnih pogojev (slika 3), v katerih smo manipulirali dve neodvisni spremenljivki: prikaz tarč, ki označuje stran zaslona, s katere so si udeleženci morali zapomniti orientacijo tarčnih dražljajev in se sklada zzačetnim namigom (enostranski - levo in desno, obojestranski), in število tarč, predstavljenih na relevantni strani zaslona (1, $2,3,4,6)$. Pri enostranskem prikazu tarč (levo, desno) smo udeležencem prikazali 1, 2, 3, 4 ali 6 dražljajev na vsaki strani zaslona (10 eksperimentalnih pogojev). Pri obojestranskem prikazu tarč smo udeležencem prikazali 1,2 ali 3 tarče na vsaki strani zaslona, kar sovpada z 2, s 4 ali 6 tarčami, razporejenimi preko obeh strani zaslona (trije eksperimentalni pogoji). Kapaciteto vidnega delovnega spomina za prikaz 14 tarč smo preverjali na podlagi spoznanj predhodnih študij (Cowan, 2010), ki kažejo, da je kapaciteta vidnega delovnega spomina v povprečju omejena na 3-4 objekte. Ker bi bilo možno, da bi v vzorec udeležencev zajeli posameznika $\mathrm{z}$ večjo kapaciteto, smo v eksperimentalni načrt vključili tudi pogoj z višjo spominsko obremenitvijo. Zaradi dolgotrajne

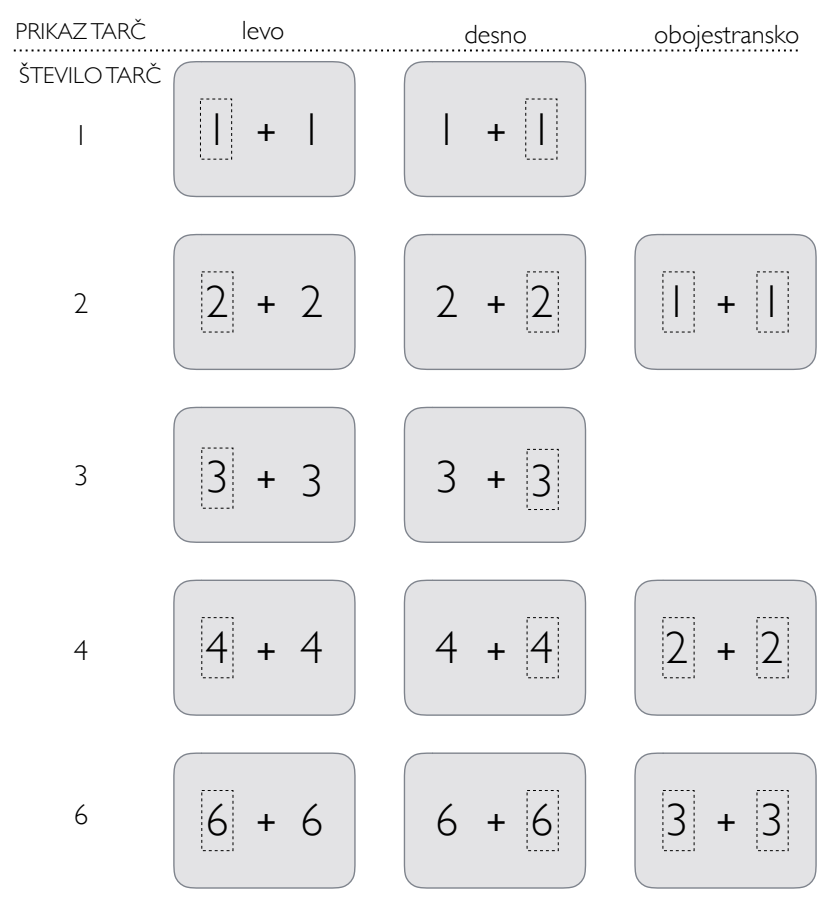

Slika 3. Ponazoritev eksperimentalnih pogojev.

Eksperimentalni pogoji so razvrščeni glede na prikaz tarč in njihovo število. Števila v okvirčkih označujejo število dražljajev (pravokotnikov različnih orientacij), prikazanih na levi in desni strani zaslona v posameznem eksperimentalnem pogoju. Črtkana črta okoli števil označuje tarčne dražljaje, na katere so morali biti udeleženci $\mathrm{v}$ danem pogoju pozorni in so morali vzdrževati njihovo orientacijo.

izvedbe eksperimenta z že predvidenimi eksperimentalnimi pogoji (prikaz 1-4 tarč) smo izpustili prikaz petih tarč, dodali pa pogoj šestih tarč, saj bi le-ta omogočil prepoznati posameznike s kapaciteto do šest orientacij.

Sočasna naloga verbalne potlačitve. Da bi udeležencem onemogočili verbalno prekodiranje vidno predstavljenih dražljajev, so sočasno z nalogo vidnega delovnega spomina izvajali tudi nalogo verbalne potlačitve. En poskus naloge verbalne potlačitve se je pojavljal na vsakih osem poskusov naloge vidnega delovnega spomina (slika 2). Pred začetkom prvega poskusa naloge vidnega delovnega spomina je bil za 2000 ms predstavljen niz štirih modro obarvanih črk (tarče). Udeleženci so si morali niz črk zapomniti in ga vzdrževati med izvajanjem osmih poskusov naloge vidnega delovnega spomina. Po osmih poskusih naloge verbalne potlačitve je bil za 200 ms prikazan testni niz črk v rdeči barvi. Niz črk je bil bodisi enak prvotno prikazanemu nizu bodisi se je $\mathrm{v}$ eni črki razlikoval. Udeleženci so morali med prikazom testnega niza črk s pritiskom gumba na tipkovnici označiti, ali sta se tarčni in testni niz črk razlikovala. Po odgovoru se je prikazal nov niz tarčnih črk, ki so ga udeleženci morali vzdrževati naslednjih osem poskusov naloge vidnega delovnega spomina. Morebitni vpliv naloge verbalne potlačitve na nalogo vidnega delovnega spomina je bil enak za vse eksperimentalne pogoje, zaradi česar njena uporaba ne bi smela vplivati na naslavljanje zastavljenega raziskovalnega vprašanja. 


\section{Postopek}

Zbiranje podatkov je potekalo v zvočno izolirani sobi, kar je udeležencem omogočilo, da so se nalogi posvetili brez motenj. Po podpisu obveščenega soglasja smo udeležencem podali natančna navodila za izvedbo naloge. Eksperimentator jim je najprej predstavil nalogo vidnega delovnega spomina $\mathrm{s}$ pomočjo štirih poskusov in nalogo verbalne potlačitve $s$ pomočjo enega poskusa. Ko se je eksperimentator prepričal, da udeleženec navodila razume, je udeleženec sodeloval v kratki vaji, katere namen je bil spoznati se z eksperimentalnim postopkom in načinom podajanja odgovorov. Vaja je vsebovala osem poskusov naloge vidnega delovnega spomina in dva poskusa naloge verbalne potlačitve (naloga potlačitve se je v vaji pojavila na vsake štiri poskuse naloge vidnega delovnega spomina).

Udeleženci so nato izvedli testni del preizkušnje, ki je potekal v 12 blokih. Vsak blok je vseboval 32 poskusov naloge vidnega delovnega spomina (skupno 384 poskusov) in 4 poskuse naloge verbalne potlačitve (skupno 48 poskusov). Zaporedje eksperimentalnih pogojev je bilo psevdorandomizirano, tako da je bilo znotraj 16 zaporednih poskusov naloge vidnega delovnega spomina zajetih vseh 13 eksperimentalnih pogojev, pri čemer je bil vsak izmed treh pogojev obojestranskega prikaza tarč zajet $\mathrm{v}$ dva poskusa ( $\mathrm{z}$ namigom za odgovor, ki je nakazoval levo, in $\mathrm{z}$ namigom za odgovor, ki je nakazoval desno stran zaslona). Znotraj celotnega eksperimenta se je vsaka eksperimentalna kombinacija pojavila 24-krat.

$\mathrm{Za}$ podajo odgovora so udeleženci na računalniški tipkovnici pritisnili črko " $\mathrm{n}$ " za odgovor ni spremembe (testni niz je enak tarčnemu nizu) in črko "m" za odgovor je sprememba (testni niz se razlikuje od tarčnega niza). Da bi izključili možne učinke izbora tipk, je polovica udeležencev za podajo odgovora uporabila obratno razporeditev ter pritisnila črko "n" za odgovor je sprememba in črko "m" za odgovor ni spremembe.

\section{Analiza podatkov}

Oceno kapacitete delovnega spomina $(K)$ smo izračunali na podlagi pravilnosti odgovorov s Pashlerjevo (1988) formulo (enačba 1).

$$
K=\frac{N \times(h-f)}{(1-f)}
$$

V enačbi $1 h$ predstavlja deležzadetkov (pravilnih potrditev spremembe), $f$ delež zmotnih alarmov (nepravilnih potrditev spremembe), $N$ pa število tarčnih dražljajev (Pashler, 1988; za podrobnosti glej Rouder, Morey, Morey in Cowan, 2011).

Na podlagi ocenjene kapacitete delovnega spomina smo izračunali dve dodatni meri (slika 4): obojestranski potencial (OP) in obojestranski indeks kapacitete (OI). Obojestranski potencial smo izračunali kot vsoto najvišje ocenjenih kapacitet za enostranski prikaz tarč na levi $\left(\mathrm{K}_{\mathrm{L}}\right)$ in desni $\left(\mathrm{K}_{\mathrm{D}}\right)$ strani zaslona (najvišja ocenjena kapaciteta za levo in desno

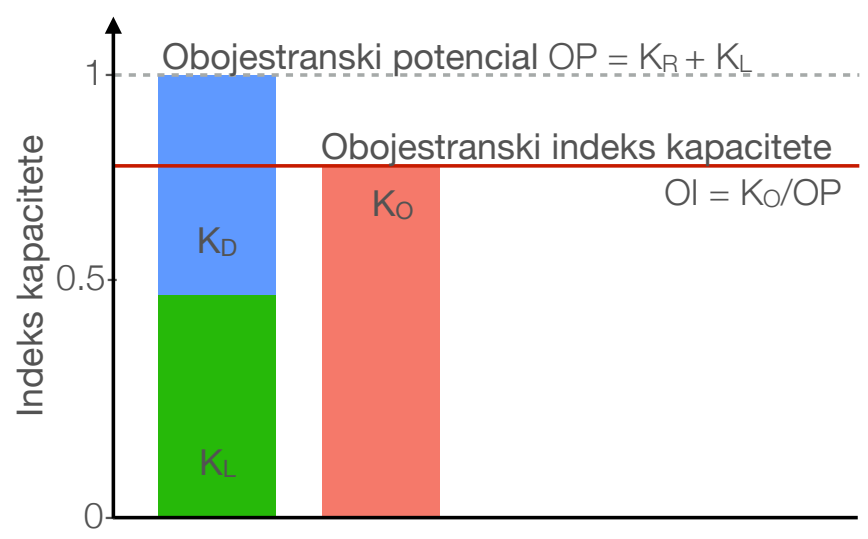

Slika 4. Ponazoritev mer, uporabljenih v statistični analizi: obojestranski potencial (OP, označen s prekinjeno sivo črto) in obojestranski indeks kapacitete (OI, označen z rdečo črto).

stran je bila izbrana med vsemi vrednostmi izračunanih kapacitet za prikaz 1, 2, 3, 4 in 6 tarč za vsakega udeleženca posebej). Obojestranski indeks kapacitete (OI) smo izračunali kot razmerje med najvišje ocenjeno obojestransko kapaciteto $\left(\mathrm{K}_{\mathrm{B}}\right)$ in obojestranskim potencialom (OP). Obojestranski indeks kapacitete 1 bi kazal na to, da si lahko udeleženec na obeh straneh zaslona naenkrat zapomni toliko, kot je njegov obojestranski potencial. Indeks, nižji od 1, bi kazal, da kapaciteta za dražljaje, prikazane obojestransko, ne doseže obojestranskega potenciala. Analogno obojestranskemu indeksu kapacitete smo dodatno izračunali tudi levi in desni indeks kapacitete, in sicer kot razmerje med najvišje ocenjeno kapaciteto za levi $\left(\mathrm{K}_{\mathrm{L}}\right)$ ali desni prikaz $\left(\mathrm{K}_{\mathrm{D}}\right)$ in obojestranskim potencialom (OP).

Pri analizi reakcijskih časov smo upoštevali samo pravilne odgovore. Da bi odstranili možne osamelce, reakcijskih časov, krajših od $200 \mathrm{~ms}$ in daljših od $2000 \mathrm{~ms}$ (kot je bilo omejeno s časom za odgovor), ter reakcijskih časov, ki so odstopali dve standardni deviaciji ali več od povprečja znotraj posameznega eksperimentalnega pogoja (izračunano za vsakega udeleženca posebej), nismo upoštevali. Povprečja za vsakega udeleženca pri vsakem pogoju smo izračunali po odstranitvi takih osamelcev.

Rezultatov pri sočasni nalogi verbalne potlačitve nismo podrobneje obravnavali, saj je naloga služila le kot kontrola preprečevanja verbalizacije orientacije dražljajev. Rezultate smo pregledali le za namen prepoznave posameznikov, katerih pravilnost pri nalogi je bila manjša od 75 odstotkov, zaradi česar nismo mogli zagotoviti, da si pri nalogi vidnega delovnega spomina niso pomagali s strategijami verbalizacije (priloga, slika P1).

Vse analize smo izvedeli s pomočjo programa R (R Core Team, 2014). Uporabili smo vgrajeno funkcijo t.test za $t$-test za en vzorec. Za izračun Cohenovega $d$ kot mere velikosti učinka smo uporabili funkcijo cohens $D$ iz knjižnice lsr (Navarro, 2015), za analizo variance in mero velikosti učinka $\eta^{2}$ (eta kvadrat) pa funkcijo ezANOVA iz knjižnice $e z$ (Lawrence, 2013). Za slikovni prikaz podatkov smo uporabili knjižnico ggplot2 (Wickham, 2009). 


\section{Rezultati}

\section{Učinek prikaza dražljajev in njihovega števila na kapaciteto vidnega delovnega spomina}

Najprej smo preverili, ali je $K$, ocena števila uspešno vkodiranih in vzdrževanih orientacij, različen glede na stran vidnega polja, torej kadar so dražljaji prikazani na levi ali desni strani zaslona. Dvosmerna analiza variance (ANOVA) za ponovljene meritve $\mathrm{z}$ dejavnikoma vidno polje (levo, desno) in število tarč $(1,2,3,4,6)$ je pokazala glavni učinek števila tarč, $F(1,17)=41,8, p<0,001, \eta^{2}=0,531$. To odraža višjo ocenjeno kapaciteto delovnega spomina pri enostranskem prikazu z večanjem števila tarč (slika 5A, glej zeleno in modro krivuljo). Učinek vidnega polja, $F(1,17)=0,025, p=0,877$, $\eta^{2}<0,001$, in interakcija vidno polje $\times$ število tarč, $F(1,17)=$ $0,372, p=0,550, \eta^{2}=0,007$, se nista izkazala kot statistično značilna, kar kaže na to, da se kapaciteta delovnega spomina pri enostranskem prikazu tarč ne razlikuje med posamezniki glede na vidno polje, v katerem so bile tarče predstavljene. Iz tega razloga smo $v$ nadaljevanju za oceno enostranske kapacitete povprečili kapaciteto, izmerjeno pri prikazu tarč na levi in desni strani (rezultati se ob upoštevanju samo leve ali desne strani za enostranski prikaz ne spremenijo).

$\mathrm{V}$ nadaljevanju smo preverili, ali je ocenjeno število uspešno vzdrževanih orientacij pri nalogi vidnega delovnega spomina večje, kadar je enako število tarčnih dražljajev prikazanih preko obeh strani zaslona (obojestranski prikaz) $\mathrm{v}$ primerjavi s prikazom na levi ali desni strani zaslona (enostranski prikaz). Dvosmerna ANOVA za ponovljene meritve $\mathrm{z}$ dejavnikoma prikaz (obojestranski, enostranski) in število tarč (kontinuirana numerična spremenljivka $\mathrm{Z}$ vrednostmi 2, 4, 6) je pokazala statistično značilen učinek prikaza tarč, $F(1,17)=17,0, p<0,001, \eta^{2}=0,242$, kar odraža višjo oceno števila uspešno vzdrževanih orientacij v primeru obojestranskega prikaza tarč. Kot statistično značilna sta se izkazala tudi učinek števila tarč, $F(1,17)=59,2, p<0,001, \eta^{2}$ $=0,578$, in interakcija med številom in prikazom tarč, $F(1,17)$ $=14,1, p=0,002, \eta^{2}=0,194$, kar kaže, da je bila obojestranska prednost najvidnejša pri višjih spominskih obremenitvah, tj. prikazu štirih in šestih tarč, in neopazna pri majhnih obremenitvah, tj. prikazu dveh tarč (glej sliko 5A).

Kot zadnje nas je zanimalo, ali obojestranska prednost doseže obojestranski potencial, izračunan kot vsota maksimalne ocenjene kapacitete leve in desne hemisfere (slika 6). V ta namen smo obojestransko prednost, izraženo z obojestranskim indeksom kapacitete, primerjali z 1, kar bi sovpadalo s tem, da bi bila obojestranska kapaciteta enaka obojestranskemu potencialu posameznika. Ker obojestranski indeksi niso statistično značilno odstopali od normalne porazdelitve, $W=0,97, p=0,848$, smo uporabili enosmerni $t$ test za en vzorec in obojestranski indeks kapacitete primerjali z 1. Analiza je pokazala, da se je obojestranski indeks kapacitete pomembno razlikoval od $1, t(17)=-12,04, p<0,001, d=$ $-2,84$, kar kaže, da preko udeležencev obojestranska prednost ni dosegla polnega obojestranskega potenciala (slika 6A). Razvrstitev udeležencev po velikosti indeksa obojestranske kapacitete (slika 6B) je dodatno pokazala, da so se udeleženci po obojestranski prednosti razlikovali. Medtem ko so nekateri skoraj dosegli svoj obojestranski potencial, pri nekaterih obojestranske prednosti ni bilo zaznati.
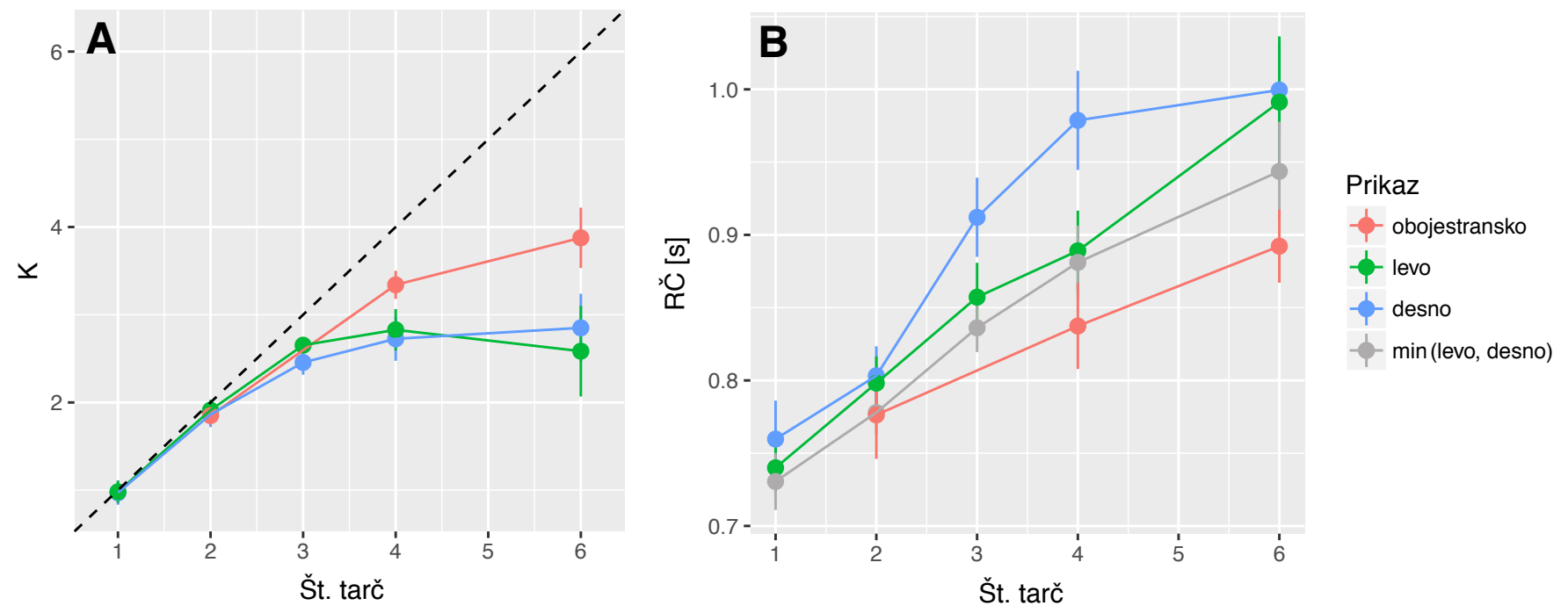

Slika 5. Ocenjeno število uspešno vzdrževanih orientacij v delovnem spominu (K) in reakcijski čas (RČ) glede na prikaz in število tarč. (A) Povprečen K je prikazan za obojestranski in enostranski (levo, desno) prikaz dražljajev glede na število prikazanih tarč. Črtkana diagonalna črta označuje teoretični maksimum ocenjenega števila uspešno vzdrževanih orientacij (K), ki bi ga lahko izmerili pri določenem številu prikazanih tarč. (B) Povprečni reakcijski časi so prikazani za obojestranski in enostranski (levo, desno in manjšo od obeh vrednosti) prikaz. Ročaji: 95-odstotni Cousineau-Moreyjev interval zaupanja za odvisne vzorce. Neprekrivajoči se intervali zaupanja sovpadajo s statistično značilnimi razlikami, kot bi bilo izračunano z ANOVO ali $t$-testom za odvisne vzorce (Baguley, 2012). 


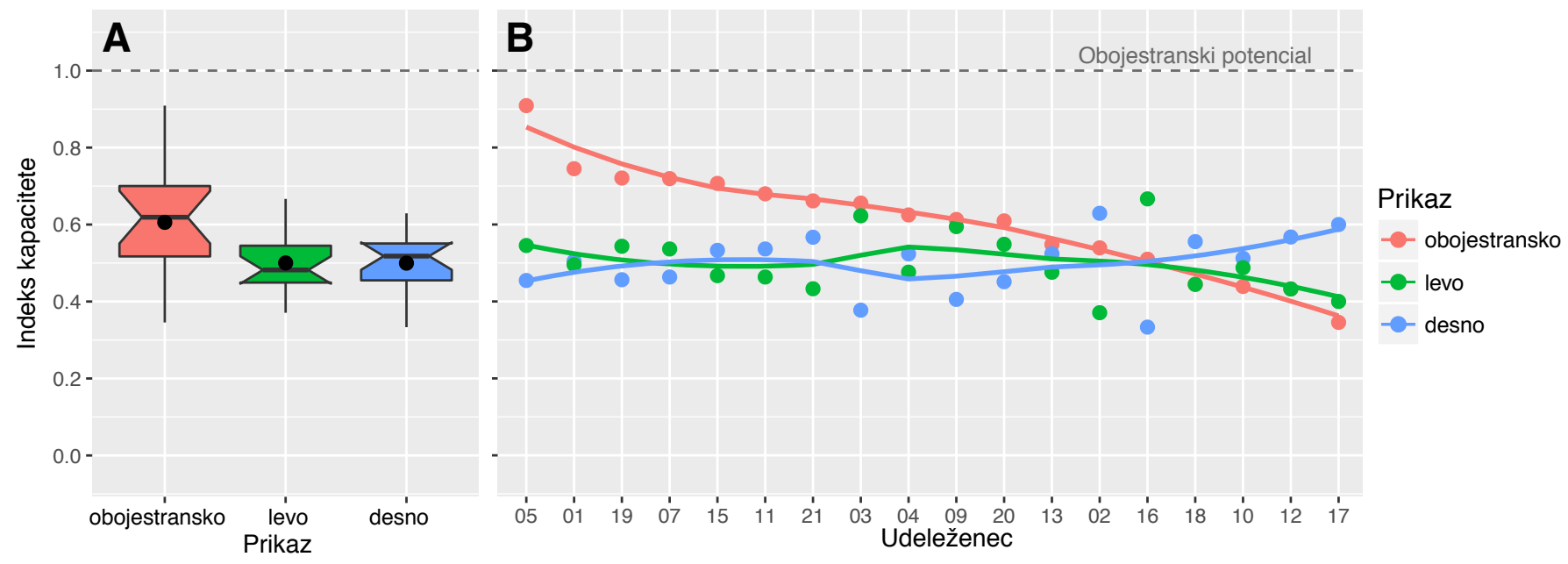

Slika 6. Indeksi kapacitete. (A) Zaboj z ročaji (angl. boxplot) za obojestranski, levi in desni indeks kapacitete. Odebeljena črta v zaboju predstavlja mediano, zgornji in spodnji rob zaboja tretji $\left(Q_{3}\right)$ in prvi $\left(Q_{1}\right)$ kvartil, zgornji ročaj predstavlja $Q_{3}+1,5$ $\cdot\left(Q_{3}-Q_{1}\right)$ in spodnji $Q_{3}+1,5 \cdot\left(Q_{3}-Q_{1}\right)$. Črna pika je aritmetična sredina. (B) Indeksi kapacitete za vsakega posameznika, posebej razvrščeni glede na velikost obojestranskega indeksa kapacitete. Vsota levega in desnega indeksa kapacitete je pri posamezniku vedno 1; indeks obojestranskega potenciala 1 bi sovpadal s tem, da bi bila obojestranska kapaciteta enaka obojestranskemu potencialu posameznika (na sliki označeno s sivo prekinjeno črto).

\section{Učinek prikaza dražljajev in njihovega števila na reakcijski čas}

Analogno z analizo pravilnosti odgovorov smo pri analizi reakcijskih časov najprej preverili, ali prihaja do razlik med reakcijskimi časi, kadar udeleženci podajajo odgovore za tarče, prikazane na desni in levi strani zaslona. Dvosmerna ANOVA za ponovljene meritve $\mathrm{z}$ dejavnikoma vidno polje (levo, desno) in število tarč $(1,2,3,4,6)$ je pokazala statistično značilen učinek števila tarč, $F(1,17)=70,7, p<$ $0,001, \eta^{2}=0,728$, in vidnega polja, $F(1,17)=9,53, p<0,001$, $\eta^{2}=0,101$, kar odraža daljšanje reakcijskih časov $\mathrm{z}$ večanjem števila tarč in daljše reakcijske čase za tarče, prikazane na desni strani zaslona oziroma $\mathrm{v}$ levem vidnem polju (slika 5B). Interakcija med vidnim poljem in številom tarč ni bila statistično značilna, $F(1,17)=0,156, p=0,698, \eta^{2}=0,001$.

Ker so se pri hitrosti procesiranja tarč, prikazanih na levi in desni strani zaslona, pojavile statistično značilne razlike, smo pri preverjanju razlik $\mathrm{v}$ hitrosti procesiranja med enostranskim in obojestranskim prikazom tarč za mero hitrosti odgovarjanja pri enostranskem prikazu upoštevali manjšo od vrednosti reakcijskega časa, izmerjenega za prikaz levo in desno. Dvosmerna ANOVA za ponovljene meritve je pokazala statistično značilen učinek števila tarč $(2,4,6)$, $F(1,17)=45,3, p<0,001, \eta^{2}=0,470$, kot tudi interakcije med številom in prikazom tarč (enostranski, obojestranski), $F(1,17)=4,56, p=0,046, \eta^{2}=0,027$, medtem ko se glavni učinek prikaza tarč ni izkazal kot statistično značilen, $F(1$, 17) $=2,09, p=0,166, \eta^{2}=0,065$ (glej tudi sliko 5B, rdečo in sivo krivuljo). Rezultati analize kažejo, da so se reakcijski časi daljšali s povečevanjem števila tarč in da je bila prednost obojestranskega procesiranja tarč večja pri višjih spominskih obremenitvah.

\section{Razprava}

Eno izmed temeljnih raziskovalnih vprašanj na področju preučevanja vidnega delovnega spomina se nanaša na mehanizme vzdrževanja vidnih informacij, ki so podlaga za njegovo omejeno kapaciteto. V raziskavi nas je zanimalo, kako k temu prispeva organiziranost možganskega sistema za procesiranje vidnih informacij. Glede na dosedanja spoznanja, ki kažejo obojestransko prednost pri hranjenju informacij $\mathrm{v}$ vidnem delovnem spominu, je bil cilj naše raziskave preveriti, na kateri stopnji obremenjenosti vidnega delovnega spomina pride do obojestranske prednosti ter ali se le-ta odraža tako v kapaciteti kot v hitrosti procesiranja informacij. Dodatno smo se posvetili vprašanju, ali lahko obojestranski prikaz informacij omogoči poln izkoristek kapacitete leve in desne hemisfere.

\section{Obojestranska prednost je opazna šele pri višjih spominskih obremenitvah}

Rezultati naše raziskave so skladni s spoznanji predhodnih raziskav (za pregled glej Delvenne, 2012), ki kažejo, da je ocenjena kapaciteta delovnega spomina višja $\mathrm{v}$ primeru obojestranskega prikaza tarčnih objektov, in nakazujejo, da udeleženci pri vzdrževanju informacij, predstavljenih preko obeh polovic vidnega polja, izkoriščajo spominski potencial obeh hemisfer. To je skladno s predpostavko, da imata leva in desna hemisfera vsaj do določene mere neodvisne vire za vzpostavljanje in vzdrževanje vidnih reprezentacij, pri čemer omogoča vključitev obeh hemisfer boljšo izvedbo pri nalogah vidnega delovnega spomina. Na podlagi odkritij o organiziranosti možganskega sistema za procesiranje vidnih informacij sklepamo, da je opažena obojestranska prednost 
rezultat procesov posteriornih, kontralateralno organiziranih področij možganske skorje (Bullier, 2004), ki so pomembni pri reprezentaciji vidnih informacij $\mathrm{v}$ odsotnosti zunanjih dražljajev (Eriksson idr., 2015).

Nadalje smo se osredotočili na vprašanje, na kateri stopnji obremenjenosti vidnega delovnega spomina je obojestransko prednost mogoče zaznati. Rezultati se ujemajo s predpostavko, da bo do le-te prišlo pri višjih spominskih obremenitvah, medtem ko pri manjših spominskih obremenitvah ne bo opazna. Rezultati kažejo, da sta pri nizki spominski obremenitvi (prikaz dveh tarč) tako leva kot desna hemisfera vsaka sposobni vzdrževati oba prikazana objekta, zaradi česar obojestranski prikaz tarč ne omogoča prednosti pri številu vzdrževanih objektov. V primerih enostranskega prikaza večjega števila tarč (4 in 6) pa vsaka posamezna hemisfera ni sposobna vzdrževati vseh prikazanih tarč - v teh primerih obojestranski prikaz tarč omogoča, da lahko posamezniki vzdržujejo več tarč kot takrat, ko je v vzdrževanje informacij vključena le posamezna hemisfera. Prednost obojestranskega prikaza dražljajev se tako opazi šele, ko število tarč preseže kapaciteto posamične hemisfere.

Podoben vzorec rezultatov smo opazili tudi pri reakcijskih časih, ki se prinižjih spominskih obremenitvahniso razlikovali glede na enostranski ali obojestranski prikaz dražljajev, medtem ko je bil pri višjih spominskih obremenitvah (6 tarč) čas za odgovor v primeru obojestranskega prikaza krajši. Rezultati kažejo na učinkovitejše procesiranje objektov, kadar so ti prikazani preko obeh polovic vidnega polja, kar se sklada z modeli vzporednega procesiranja objektov (Kraft idr., 2013), ki predpostavljajo, da je vzporedno procesiranje objektov učinkovitejše, kadar pri tem sodelujeta obe hemisferi $\mathrm{v}$ nasprotju $\mathrm{z}$ eno samo hemisfero.

\section{Obojestranski prikaz ne omogoča polnega izkoristka kapacitet leve in desne hemisfere}

$Z$ raziskavo smo uspešno replicirali dosedanja spoznanja o obojestranski prednosti $\mathrm{v}$ vidnem delovnem spominu ter jih - kot je predstavljeno $\mathrm{v}$ prejšnjem razdelku - razširili $\mathrm{z}$ ugotovitvijo, da ima pri tem pomembno vlogo spominska obremenitev. V nadaljevanju smo se osredotočili na vprašanje, ali obojestranski prikaz udeležencem omogoča poln izkoristek kapacitet obeh hemisfer, pri čemer smo predpostavljali, da je kapacitetni potencial, ki ga lahko udeleženci dosežejo pri obojestranskem prikazu, enak vsoti kapacitete leve in desne hemisfere. Rezultati so pokazali, da obojestranski prikaz posameznikom ne omogoča polnega izkoristka kapacitet obeh hemisfer.

Če bi se izkazalo, da je obojestranska kapaciteta enaka vsoti kapacitet posameznih hemisfer, bi lahko sklepali, da omejitev kapacitete vidnega delovnega spomina primarno temelji na zmogljivosti posteriornih področij možganov leve in desne hemisfere, ki beležijo reprezentacije vidnih objektov v delovnem spominu. Ker pa je ocenjena obojestranska kapaciteta presegla ocenjeno kapaciteto vsake posamezne hemisfere in bila hkrati manjša od njune vsote, to kaže, da je kapaciteta vidnega delovnega spomina omejena ne le s sposobnostjo oblikovanja neodvisnih vidnih reprezentacij v posteriornih področjih možganske skorje, temveč je nadalje omejena $\mathrm{z}$ zmogljivostjo dodatnih področij možganov, ki omogočajo aktivno vzdrževanje vzpostavljenih reprezentacij v odsotnosti zunanjih dražljajev. Možen razlog za to so prefrontalna področja možganske skorje, ki so bila v več študijah (Eriksson idr., 2015; Riggall in Postle, 2012) že prepoznana kot pomembna pri aktivnem vzdrževanju informacij. Prefrontalna področja možganske skorje v primerjavi s posteriornimi vidnih informacij ne procesirajo kontralateralno, kar pomeni, da bi ta področja lahko pomagala pri aktivnem vzdrževanju reprezentacij, kodiranih v posteriornih področjih tako leve kot desne hemisfere.

$\mathrm{Na}$ podlagi rezultatov lahko oblikujemo konceptualni model, ki predvideva, da sta v vzpostavljanje in vzdrževanje informacij vključena dva sistema: reprezentacijski, ki omogoča vzpostavitev omejenega števila vidnih reprezentacij in je predvidoma vezan na zmogljivost posteriornih, zgodnjih področjih možganov za vidno procesiranje, in sistem za aktivno vzdrževanje, ki je vezan na prefrontalna področja, katerega naloga je aktivno vzdrževanje vzpostavljenih reprezentacij v posteriornih področjih.

S predlaganim modelom se skladajo ugotovitve predhodnih študij. Alvarez in Cavanagh (2005) sta ugotovila, da je prišlo do skoraj dvakratnega povečanja kapacitete vidnega sledenja objektom, ko so bili objekti predstavljeni preko obeh polovic vidnega polja, $\mathrm{v}$ primerjavi $\mathrm{z}$ enostransko predstavitvijo. Naloga vidnega sledenja od udeležencev ni zahtevala vzdrževanja informacij $\mathrm{v}$ delovnem spominu, temveč zgolj usmerjanje pozornosti na dražljaje, prikazane na zaslonu. Ti rezultati podpirajo obstoj dveh neodvisnih sistemov v levi in desni hemisferi, ki ob hkratnem delovanju omogočata skoraj popoln izkoristek njunih kapacitet za procesiranje informacij. V nasprotju s tem naši rezultati kot tudi rezultati drugih študij obojestranske prednosti v vidnem delovnem spominu (npr. Delvenne, 2005; Holt, 2014; Holt in Delvenne, 2015; Umemoto idr., 2010; Zhang idr., 2018) ne kažejo dvakratnega povečanja kapacitete pri vzdrževanju objektov v pogoju obojestranskega prikaza, kar kaže na obstoj dodatnega sistema, ki omejuje kapaciteto vidnega delovnega spomina na višji ravni in verjetno ni organiziran kontralateralno, temveč lahko njegova kapaciteta dodeljuje sredstva za vzdrževanje reprezentacij tako levi kot desni hemisferi.

Čeprav naša študija kaže, da je kapaciteta vidnega delovnega spomina omejena $\mathrm{z}$ dvema sistemoma, rezultati ne prinašajo dokazov o njunih specifičnih vlogah. Predpostavka, da se navezujeta na vzpostavljanje vidnih reprezentacij in njihovo aktivno vzdrževanje, je sicer najskladnejša $s$ predhodnimi ugotovitvami (za pregled glej Eriksson idr., 2015), bi pa bilo treba za podrobnejšo opredelitev izvesti dodatne eksperimentalne študije, s katerimi bi lahko podrobneje raziskali mehanizme v ozadju.

\section{Razlike v obojestranskem potencialu}

Čeprav udeleženci pri obojestranskem prikazu objektov v povprečju niso dosegli obojestranskega potenciala, so rezultati pokazali, da so glede stopnje obojestranske prednosti med njimi opazne razlike. Nekateri udeleženci so skoraj dosegli svoj potencial, medtem ko pri drugih obojestranska prednost ni bila vidna. V okviru zasnovanega konceptualnega modela bi lahko predpostavili, da te razlike odražajo razlike 
v zmogljivosti sistema za aktivno vzdrževanje vidnih reprezentacij, vezanega na prefrontalna področja možganske skorje. Opisano predpostavko bi bilo treba podrobneje nasloviti v nadaljnjih študijah, s katerimi bi bilo možno poleg vedenjskih odzivov spremljati tudi aktivnost možganov.

Opažene individualne razlike v obojestranski prednosti tako odpirajo možnosti za nadaljnje raziskovanje vidnega delovnega spomina ne le pri mladih zdravih udeležencih, temveč $\mathrm{v}$ sklopu zdravega staranja (Braver in West, 2007) in bolezni možganov (Goldman-Rakic, 1994), za katera je značilen upad zmogljivosti delovnega spomina. Implementacija preprostejše in čistejše različice naloge bi lahko omogočila spremljanje upada kapacitete glede na posamezen predlagani sistem. Naloga bi lahko služila kot diagnostični pripomoček, ki bi pomagal prepoznati, kateri izmed dveh sistemov, reprezentacijski ali sistem za aktivno vzdrževanje, je primarno okvarjen.

Spominski upad pri zdravem staranju je npr. tesno povezan $\mathrm{z}$ izvršilnimi funkcijami in $\mathrm{s}$ tem $\mathrm{s}$ sposobnostmi prefrontalne možganske skorje. V tem primeru bi pričakovali, da bi se spominski upad odražal predvsem pri znižanju obojestranske prednosti, kar bi kazalo na upad zmogljivosti sistema za aktivno vzdrževanje, manj pa pri upadu obojestranskega potenciala, ki neposredneje odraža kapaciteto posamičnih hemisfer in s tem zmogljivost reprezentacijskega sistema za vzpostavljanje vidnih reprezentacij. Drugačen vzorec rezultatov bi pričakovali pri kakšni drugi nevrološki ali nevrodegenerativni bolezni, ki primarno prizadene posteriorne predele možganov.

\section{Omejitve raziskave in predlogi za nadaljnje študije}

Medtem ko smo v eksperimentalnem načrtu sledili postopkom mnogih drugih eksperimentov, ki so uporabljali nalogo prepoznave sprememb (za pregled glej Luria idr., 2016), smo opazili nekaj potencialnih omejitev, na katere moramo biti pozorni pri interpretaciji rezultatov. Čeprav smo udeležence prosili, naj v času vkodiranja in vzdrževanja tarčnih dražljajev pogled usmerjajo na fiksacijsko točko, njihovega pogleda nismo nadzorovali. Če udeleženci navodil niso upoštevali in so svoj pogled v primeru enostranskega prikaza tarčnih dražljajev usmerjali na stran zaslona, na kateri so bili dražljaji prikazani, bi to lahko vodilo v obojestransko vkodiranje dražljajev. V tem primeru bi udeleženci tarče, prikazane na eni strani zaslona, vkodirali s pomočjo obeh hemisfer, kar bi vodilo do precenjevanja spominske kapacitete vsake posamezne hemisfere. To bi vodilo $k$ napačni, tj. povišani oceni obojestranskega potenciala in bi se kazalo $\mathrm{v}$ zmanjšani oceni obojestranskega indeksa kapacitete. Če bi bila situacija takšna, obojestranske prednosti ne bi opazili. Ker rezultati analize kažejo na pomembno obojestransko prednost, sklepamo, da udeleženci, vsaj $\mathrm{v}$ večini, niso uporabljali te strategije. Da bi lahko z gotovostjo trdili, da noben izmed udeležencev ni uporabljal takšne strategije, bi bilo smiselno uporabiti sledilec očesnih gibov, s katerim bi lahko nadzirali smer pogleda.

Druga možna težava se nanaša na prisotnost motečih dražljajev v pogojih enostranskega prikaza tarč. Kadar smo udeležencem tarče prikazovali na eni strani vidnega polja, so bili na drugi strani zaslona hkrati prikazani moteči dražljaji. To bi lahko potencialno povzročilo, prvič, da bi jih udeleženci poskušali vkodirati in vzdrževati, čeprav navodila tega od njih niso zahtevala, in drugič, da so bili njihovi viri za procesiranje $\mathrm{v}$ primeru enostranskega prikaza tarč dodatno obremenjeni z nalogo inhibicije, saj je bilo za uspešno izvajanje naloge moteče dražljaje treba ignorirati. V obeh primerih bi to vodilo $\mathrm{k}$ temu, da bi kapaciteto vsake posamezne hemisfere podcenili, pri čemer bi bila realna spominska obremenitev večja od tiste, ki bi jo upoštevali v izračunu za kapaciteto. Opažena obojestranska prednost bi bila $\mathrm{v}$ tem primeru le artefakt neustreznega eksperimentalnega načrta. Kljub temu da raziskave, ki uporabljajo lateralizirano različico naloge prepoznave sprememb (npr. Vogel in Machizawa, 2004; za pregled glej Luria idr., 2016), kot smo jo uporabili mi, te možnosti ne upoštevajo, bi bilo treba za podrobnejši vpogled v možen vpliv motečih dražljajev zasnovati študijo, v kateri bi spreminjali njihovo prisotnost.

Tretja možna težava bi lahko izhajala iz prisotnosti namiga za odgovor. Udeleženci so namreč lahko samo v pogoju obojestranskega prikaza po namigu za odgovor, ki je označeval levo ali desno stran zaslona, svojo pozornost usmerili na polovico tarčnih dražljajev, kar pomeni, da so lahko drugo polovico dražljajev izpustili iz spomina. Čeprav je ta ukrep omogočil, da sta bila pogoja enostranskega in obojestranskega prikaza primerljiva $\mathrm{v}$ načinu usmerjanja pozornosti pri podajanju odgovorov, bi bilo možno, da bi bil zaradi tega pogoj obojestranskega prikaza za udeleženci enostavnejši, kar bi lahko prispevalo k višji oceni kapacitete za obojestranski prikaz dražljajev.

Možno težavo bi lahko predstavljal tudi povprečen prostorski razmik med prikazanimi dražljaji, ki je bil pri enostranskem prikazu manjši kot pri obojestranskem prikazu, saj so bili dražljaji razporejeni znotraj navideznega kvadrata na eni strani zaslona, medtem ko so bili pri obojestranskem prikazu razporejeni znotraj navideznih kvadratov na obeh straneh zaslona, s čimer je bila povprečna razdalja med dražljaji večja. To bi lahko povzročilo, da bi pri osredotočanju pozornosti na dražljaje pri enostranskem prikazu prišlo do učinka prostorske prenasičenosti (angl. crowding), zaradi česar bi jih bilo lahko težje natančno zaznati in vkodirati kot ločene objekte (Whitney in Levi, 2011). V primeru učinka prostorske prenasičenosti, bi se to odražalo $\mathrm{v}$ podcenjeni kapaciteti za levo in desno hemisfero, opažena obojestranska prednost pabi lahko bila artefakt neizenačenosti enostranskega in obojestranskega pogoja glede prostorske nasičenosti. Na drugi strani bi lahko zaradi takšnega prikaza dražljajev prišlo do podcenjene obojestranske kapacitete, saj so udeleženci pri obojestranskem prikazu za vkodiranje dražljajev morali pozornost razpršiti širše, da so lahko zajeli dražljaje, prikazane na obeh straneh vidnega polja. Izsledki predhodnih raziskav glede prostorske nasičenosti pri preučevanju vidnega delovnega spomina (McCollough, Machizawa \& Vogel, 2007) izpostavljenih potencialnih težav ne podpirajo, saj kažejo, da razdalje med predstavljenimi dražljaji nimajo vpliva ne na kapaciteto kot tudi ne na elektrofiziološke korelate kapacitete vidnega delovnega spomina.

Da bi lahko popolnoma izključili te možnosti, bi bilo pri nadaljnjih raziskavah treba zagotoviti, da bi bil prikaz dražljajev tako pri enostranskem kot pri obojestranskem 
prikazu primerljiv (npr. dražljaje bi namesto znotraj navideznih kvadratov na levi in desni strani zaslona enakomerno razporedili na navidezni krožnico okoli osrednje fiksacijske točke).

Omenjene pomanjkljivosti predstavljajo pomembno izhodišče za načrtovanje izboljšane različice eksperimenta, v katerega bi bilo smiselno vključiti tudi večje število udeležencev. To bi pripomoglo $\mathrm{k}$ verodostojnejšim rezultatom, zaradi večje statistične moči pa bi omogočilo spremljanje možnih moderatorskih učinkov pri pojasnjevanju variabilnosti obojestranskega indeksa, ki kaže, da udeleženci v različni meri izkoristijo svoj spominski potencial (npr. spol, starost, obojestranski potencial).

\section{Zaključki}

Rezultati naše študije podpirajo spoznanja predhodnih raziskav, ki kažejo obojestransko prednost pri vzdrževanju informacij $\mathrm{v}$ vidnem delovnem spominu. Predhodna spoznanja smo razširili z ugotovitvami, da je obojestransko prednost tako pri ocenjeni kapaciteti kot reakcijskih časih možno opaziti šele, ko obremenitev vidnega delovnega spomina preseže kapaciteto posamezne hemisfere. Dodatno smo pokazali, da kljub pomembni obojestranski prednosti ta udeležencem v povprečju ne omogoča, da polno izkoristijo kapacitetni potencial leve in desne hemisfere, kar kaže, da kapaciteta vidnega delovnega spomina ni omejena le $\mathrm{z}$ zmogljivostjo kontralateralno organiziranih posteriornih področij možganske skorje, ki omogočajo vzpostavljanje neodvisnih vidnih reprezentacij, temveč tudi z zmogljivostjo dodatnega kognitivnega sistema, predvidoma povezanega $\mathrm{s}$ prefrontalnimi področji možganske skorje, ki omogoča njihovo aktivno vzdrževanje v odsotnosti zunanjih dražljajev.

\section{Opombe avtorjev}

A. S. O. in G. R. sta zasnovala študijo in pripravila eksperiment; A. S. O. je zbrala podatke in jih analizirala; A. S. O. in G. R. sta napisala članek.

Raziskavo je sofinancirala Javna agencija za raziskovalno dejavnost Republike Slovenije iz državnega proračuna (projekt J7-5553, J3-9264 in program P5-0110).

Za pomoč pri zbiranju podatkov se zahvaljujemo Žigi Bogataju, Anji Negovec, Andreji Špeh in Nastji Tomat.

\section{Literatura}

Alvarez, G. A. in Cavanagh, P. (2005). Independent resources for attentional tracking in the left and right visual hemifields. Psychological Science, 16(8), 637-643.

Baddeley, A. (1996a). The fractionation of working memory. Proceedings of the National Academy of Sciences of the United States of America, 93(24), 13468-13472.

Baddeley, A. (1996b). Exploring the central executive. Quarterly Journal of Experimental Psychology, 49A(1), 5-28.

Baddeley, A. (2000). The episodic buffer: A new component of working memory? Trends in Cognitive Sciences, 4(11), 417-423.

Baddeley, A. D. in Hitch, G. J. (1974). Working memory. V G. A. Bower (ur.), Recent advances in learning and motivation (Vol. 8, str. 47-90). New York, NY, ZDA: Academic Press.

Baguley, T. (2012). Calculating and graphing within-subject confidence intervals for ANOVA. Behavior Research Methods, 44(1), 158-175.

Braver, T. S. in West, R. (2007). Working memory, executive control and aging. V F. I. M. Craik in T. A. Salthouse (ur.), The handbook of aging and cognition (str. 311-372). New York, NY, ZDA: Psychology Press.

Bublak, P., Müller, U., Grön, G., Reuter, M. in Cramon, von, D. Y. (2002). Manipulation of working memory information is impaired in Parkinson's disease and related to working memory capacity. Neuropsychology, 16(4), 577-590.

Bullier, J. (2004). Communications between cortical areas of the visual system. V L. M. Chalupa in J. S. Werner (ur.), The visual neurosciences (str. 522-540). Cambridge, MA: The visual neurosciences.

Chakravarthi, R. in Cavanagh, P. (2009). Bilateral field advantage in visual crowding. Vision Research, 49(13), 1638-1646.

Cowan, N. (2005). Working memory capacity. Hove, East Sussex, Združeno kraljestvo: Psychology Press.

Cowan, N. (2010). The magical mystery four: How is working memory capacity limited, and why? Current Directions in Psychological Science, 19(1), 51-57.

Delvenne, J.-F. (2005). The capacity of visual short-term memory within and between hemifields. Cognition, 96(3), B79-B88.

Delvenne, J.-F. (2012). Visual short-term memory and the bilateral field advantage. V G. Kalivas in S. F. Petralia (ur.), Short-term memory: New research. Nova Science.

Eriksson, J., Vogel, E. K., Lansner, A., Bergström, F. in Nyberg, L. (2015). Neurocognitive architecture of working memory. Neuron, 88(1), 33-46.

Goldman-Rakic, P. S. (1994). Working memory dysfunction in schizophrenia. The Journal of Neuropsychiatry and Clinical Neurosciences, 6(4), 348-357.

Holt, J. L. (2014). Investigating visual short-term memory capacity within and between hemifields. Experimental Psychology, 61(2), 127-133.

Holt, J. L. in Delvenne, J.-F. (2015). A bilateral advantage for maintaining objects in visual short term memory. Acta Psychologica, 154, 54-61. 
Kensinger, E. A., Shearer, D. K., Locascio, J. J., Growdon, J. H. in Corkin, S. (2003). Working memory in mild Alzheimer's disease and early Parkinson's disease. Neuropsychology, 17(2), 230-239.

Kraft, A., Dyrholm, M., Bundesen, C., Kyllingsbæk, S., Kathmann, N. in Brandt, S. A. (2013). Visual attention capacity parameters covary with hemifield alignment. Neuropsychologia, 51(5), 876-885.

Lawrence, M. A. (2013). ez: Easy analysis and visualization of factorial experiments. $\mathrm{R}$ package version 3.1.2 [računalniški program]. Pridobljeno s http://CRAN.Rproject.org/package $=$ ez.

Luck, S. J. in Vogel, E. K. (2013). Visual working memory capacity: From psychophysics and neurobiology to individual differences. Trends in Cognitive Sciences, 17(8), 391-400.

Luria, R., Balaban, H., Awh, E. in Vogel, E. K. (2016). The contralateral delay activity as a neural measure of visual working memory. Neuroscience and Biobehavioral Reviews, 62, 100-108.

Ma, W. J., Husain, M. in Bays, P. M. (2014). Changing concepts of working memory. Nature Neuroscience, 17(3), 347-356.

McCollough, A. W., Machizawa, M. G. in Vogel, E. K. (2007). Electrophysiological measures of maintaining representations in visual working memory. Cortex, 43(1), 77-94.

Navarro, D. (2015). Learning statistics with R: A tutorial for psychology students and other beginners. Pridobljeno $\mathrm{s}$ https://CRAN.R-project.org/package $=1$ sr.

Park, D. C. in Festini, S. B. (2017). Theories of memory and aging: A look at the past and a glimpse of the future. The Journals of Gerontology Series B, Psychological Sciences and Social Sciences, 72(1), 82-90.

Pashler, H. (1988). Familiarity and visual change detection. Perception in Psychophysics, 44(4), 369-378.

Peirce, J. W. (2007). PsychoPy-Psychophysics software in Python. Journal of Neuroscience Methods, 162(1-2), $8-13$.

R Core Team. (2014). The R project for statistical computing [računalniški program] . Pridobljeno s http://www.Rproject.org/.

Repovš, G. in Baddeley, A. (2006). The multi-component model of working memory: Explorations in experimental cognitive psychology. Neuroscience, 139(1), 5-21.

Riggall, A. C. in Postle, B. R. (2012). The relationship between working memory storage and elevated activity as measured with functional magnetic resonance imaging. The Journal of Neuroscience: The Official Journal of the Society for Neuroscience, 32(38), 12990-12998.

Rouder, J. N., Morey, R. D., Morey, C. C. in Cowan, N. (2011). How to measure working memory capacity in the change detection paradigm. Psychonomic Bulletin \& Review, 18(2), 324-330.

Umemoto, A., Drew, T., Ester, E. F. in Awh, E. (2010). A bilateral advantage for storage in visual working memory. Cognition, 117(1), 69-79.

Vogel, E. K. in Machizawa, M. G. (2004). Neural activity predicts individual differences in visual working memory capacity. Nature, 428(6984), 748-751.
Whitney, D. in Levi, D. M. (2011). Visual crowding: A fundamental limit on conscious perception and object recognition. Trends in Cognitive Sciences, 15(4), $160-168$.

Wickham, H. (2009). ggplot2 [računalniški program]. New York, NY, ZDA: Springer.

Zhang, Y., Ye, C., Roberson, D., Zhao, G., Xue, C. in Liu, Q. (2018). The bilateral field advantage effect in memory precision. Quarterly Journal of Experimental Psychology, 71(3), 749-758. 


\section{Priloga}

\section{Pravilnost pri nalogi verbalne potlačitve}

Sočasno z izvedbo naloge vidnega delovnega spomina so udeleženci izvajali nalogo verbalne potlačitve, katere cilj je bil preprečiti verbalno prekodiranje vidno predstavljenih dražljajev. Kriterij za vključitev podatkov udeležencev v analizo naloge vidnega delovnega spomina je bila več kot 75 -odstotna pravilnost pri nalogi verbalne potlačitve. Prepoznali smo enega udeleženca, ki ni dosegal kriterijev in ga izključili iz nadaljnih analiz, saj nismo mogli zagotoviti, da si pri nalogi vidnega delovnega spomina ni pomagal s strategijami verbalizacije (slika P1, udeleženec 14).

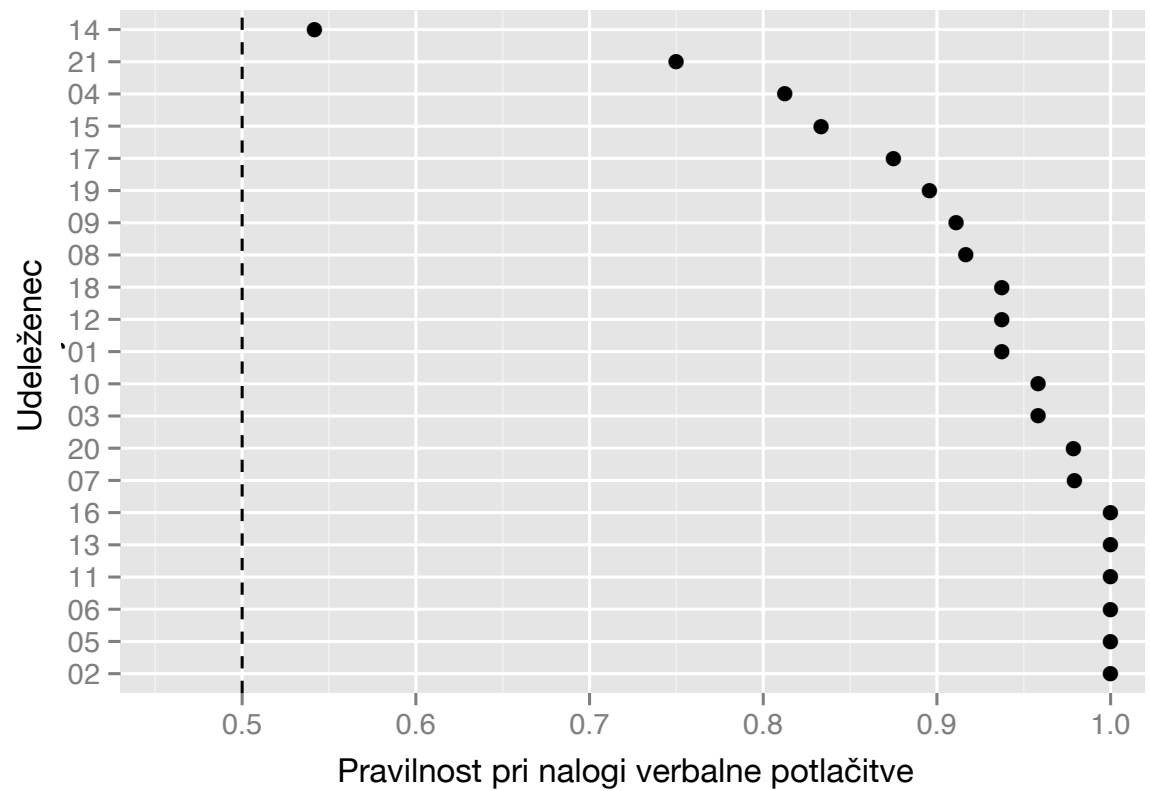

Slika P1. Pravilnost sočasne naloge verbalne potlačitve za vsakega udeleženca posebej. Udeleženci so razvrščeni glede na pravilnost.

\section{Primer prikaza eksperimentalnega pogoja šestih tarč enostransko in obojestransko}

Pri nalogi vidnega delovnega spomina so morali udeleženci prepoznati spremembo v orientaciji objektov, prikazanih na levi, desni ali na obeh straneh vidnega polja. V nalogi smo manipulirali prikaz tarč, ki označuje stran zaslona, s katere so si udeleženci morali zapomniti orientacijo tarčnih dražljajev in število tarč, predstavljenih na relevantni strani zaslona (1, 2, 3, 4, 6) (primer prikaza dražljajev za prikaz šestih tarč levo, desno in obojestransko je predstavljen na sliki P2).

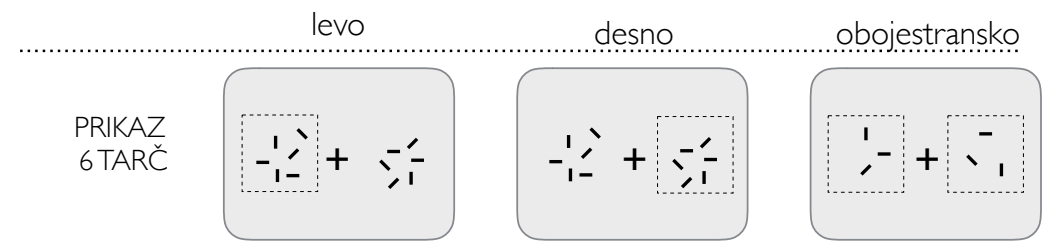

Slika P2. Primer eksperimentalnih pogojev šestih tarč enostransko (levo, desno) in šestih tarč obojestransko. Črtkan kvadrat označuje tarčne dražljaje, na katere so morali biti udeleženci v danem pogoju pozorni in so morali vzdrževati njihovo orientacijo (črtkan kvadrat med eksperimentom ni bil prikazan, saj so udeleženci informacijo o tem, na katero stran zaslona morajo biti pozorni, dobili z začetnim namigom). Pravokotniki, ki niso predstavljeni znotraj črtkanega okvirja, so bili v vlogi motečih dražljajev. 